\title{
sciendo
}

QPI 2019, volume 1, issue 1, pp. 495-502

\section{EVALUATION OF THE QUALITY OF THE PRODUCTION PROCESS PET BOTTLES}

doi: 10.2478/cqpi-2019-0067

Date of submission of the article to the Editor: 10/05/2019

Date of acceptance of the article by the Editor: 28/05/2019

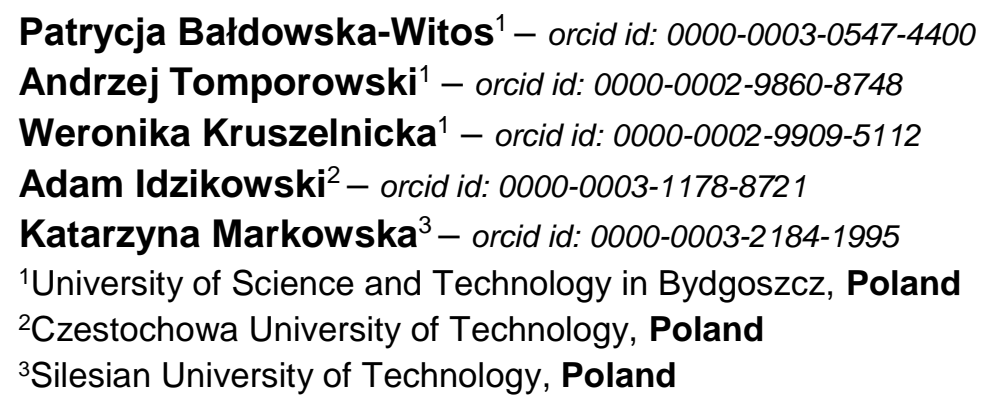

Abstract: In the article was presented the results of analysis of the nonconformities which occur during the production of PET bottles in the selected company from Poland. The analysis included six process unit operations of forming PET bottles. The aim of the analysis is to present specific corrective and improvement actions based on the results obtained. The article presents a short description of the process of shaping PET bottles for six selected operations. The block diagram of the PET bottle shaping process is presented. Quality management tools were used for quantitative and qualitative analysis. The use of the Pareto-Lorenz diagram allowed for quantitative an approach to the quality problems of PET bottles. The Ishikawa diagram was used to identify potential causes of the most frequent problem. Corrective actions were proposed to improve the quality of PET bottles tested. The research problem has been solved. As a critical element requiring improvement, the competences of employees and the process of operating machines and devices were indicated.

Keywords: Pareto-Lorenz diagram, Ishikawa diagram, product quality, plastic bottles, production process

\section{INTRODUCTION}

In the era of growing demand for high-quality products and the constant striving of the population to improve living conditions, it is very important to properly manage quality in business operations (Kadoński and Szołtysek, 2008). Quality is defined in the literature depending on your point of view, category and aspect. In technical terms, quality should be understood as a set of specific properties describing a given product, the purpose of which is to ensure useful and social usefulness. The main goal of the enterprises in the production sector is to ensure high quality products while maintaining a minimum level of occurrence of defective products (Mazur and Gołaś, 2010).

The article presents the results of analysis and evaluation of the quality of a plastic bottle made of plastic, polyethylene terephthalate. The analysis was based on an assessment of quantitative and qualitative problems occurring during the production 
process. The result of the analysis are proposed corrective and improvement actions aimed at improving the quality of production. The subject of research is the production process of PET bottles produced in a production facility in Poland. The company has a very well equipped technological line and modern logistics facilities. The company's assortment includes packaging intended for contact with food. The main recipients of finished products are domestic and foreign consumers.

\section{PET BOTTLE MANUFACTURING PROCESS}

The manufacture of plastic bottles takes place in stages. Plastic bottles used to hold potable water and other drinks are made from polyethylene terephthalate (PET), because the material is both strong and light. PET is a thermoplastic polymer that can be either opaque or transparent, depending on the exact material composition. PET is produced from petroleum hydrocarbons, through a reaction between ethylene glycol and terephthalic acid. Once the plastic itself has been manufactured, the bottle manufacturing process can begin (Kruszelnicka et al., 2018), (Kuczenski et al., 2011). The first stage in bottle manufacturing is stretch blow molding. The PET is heated and placed in a mold, where it assumes the shape of a long, thin tube. The process by which the plastic is forced into the mold is called injection molding. The tube of PET, now called a parison, is then transferred into a second, bottle-shaped mold. A thin steel rod, called a mandrel, is slid inside the parison where it fills the parison with highly pressurized air, and stretch blow molding begins: as a result of the pressurized air, heat and pressure, the parison is blown and stretched into the mold, assuming a bottle shape. The mold must be cooled relatively quickly, so that that the newly formed component is set properly. Cooling method include using pressurized air directly on the mold and plastic. Once the bottle has cooled and set, it is ready to be removed from the mold. Finished bottles are transported to the bottling plant. Thanks to the implementation of the discussed process, it is possible to manufacture products such as plastic bottles of various capacities (Kruszelnicka et al., 2018), (Ullah et al., 2016). The PET bottle manufacturing process in the surveyed enterprise consists of the following operations:

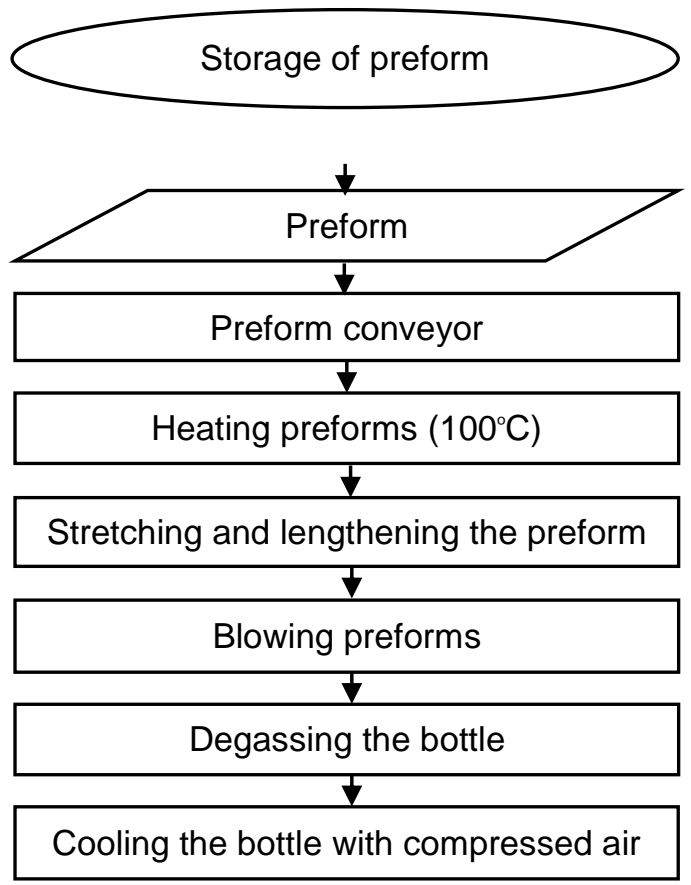

Fig. 1. Block diagram of the PET bottle production process 


\section{ANALYSIS OF RESULTS}

Table 1 shows the results of bottle defects from the monthly observation.

Table 1

Defects generated in the process of production of bottles

\begin{tabular}{|l|l|c|}
\hline No. & \multicolumn{1}{|c|}{ Types of nonconformities } & The number of nonconformities \\
\hline 1 & Wrong shape of bottles & 33 \\
\hline 2 & Incorrect length of bottles & 12 \\
\hline 3 & Bubbles on the surface of the bottles & 10 \\
\hline 4 & Bottle cracks & 6 \\
\hline 5 & Formation of several layers of the bottle & 4 \\
\hline 6 & The formation of threads or streaks on the bottle & 3 \\
\hline 7 & Too slow change in the color of the bottle & \\
\hline
\end{tabular}

Source: own research

Based on the collected research results, analyzes were carried out using the ParetoLorenz diagram and the Ishikawa diagram. The Pareto-Lorenz diagram enables the hierarchization of factors influencing the analyzed phenomenon. The creator of this method is V. Pareto coming from Italy. This rule is colloquially called $80 / 20$ (Biały et al., 2011). This means that a small number of events or situations are responsible for the majority of occurring phenomena. Allows you to specify the directions of actions aimed at improving the level of quality of products or processes. Arranges the data in terms of their validity. The Pareto chart is closely related to the principle developed by M.O. Lorenzo, who also studied uneven distributions. Hence, this method is called ParetoLorenz diagram. The use of the Pareto-Lorenz diagram allowed the quantitative approach to qualitative problems of preforms and PET bottles in the studied enterprise. The choice of this tool allowed to determine the most important reasons that most affected the product defects (Ilie et al., 2010), (Kowalik, 2018).

Data for analysis was collected for one month. The result of analyzes are defects created in the production process for various bottle volumes. A total of 75 reported noncompliance. The seven most frequent non-compliances were identified. The collected data are summarized in Table 2.

Table 2

Defects generated in the process of production of bottles

\begin{tabular}{|l|l|c|c|c|}
\hline No. & \multicolumn{1}{|c|}{$\begin{array}{c}\text { Types of } \\
\text { nonconformities }\end{array}$} & $\begin{array}{c}\text { The number of } \\
\text { nonconformities }\end{array}$ & $\begin{array}{c}\text { Percent } \\
\text { of total }\end{array}$ & $\begin{array}{c}\text { Cumulative } \\
\text { percent of total }\end{array}$ \\
\hline 1 & $\begin{array}{l}\text { Incorrect shape of PET } \\
\text { bottles }\end{array}$ & 33 & $44 \%$ & $44 \%$ \\
\hline 2 & Incorrect length of bottles & 12 & $16 \%$ & $60 \%$ \\
\hline 3 & $\begin{array}{l}\text { Bubbles on the surface of } \\
\text { the bottles }\end{array}$ & 10 & $13,34 \%$ & $73,34 \%$ \\
\hline 4 & Bottle cracks & 7 & $9,33 \%$ & $82,67 \%$ \\
\hline 5 & $\begin{array}{l}\text { Formation of several } \\
\text { layers of the bottle }\end{array}$ & 6 & $8 \%$ & $90,67 \%$ \\
\hline 6 & $\begin{array}{l}\text { The formation of threads } \\
\text { or streaks on the bottle }\end{array}$ & 4 & $5,33 \%$ & $96 \%$ \\
\hline
\end{tabular}




\begin{tabular}{|l|l|c|c|c|}
\hline 7 & $\begin{array}{l}\text { Too slow change in the } \\
\text { color of the bottle }\end{array}$ & 3 & $4 \%$ & $100 \%$ \\
\hline
\end{tabular}

Source: own research

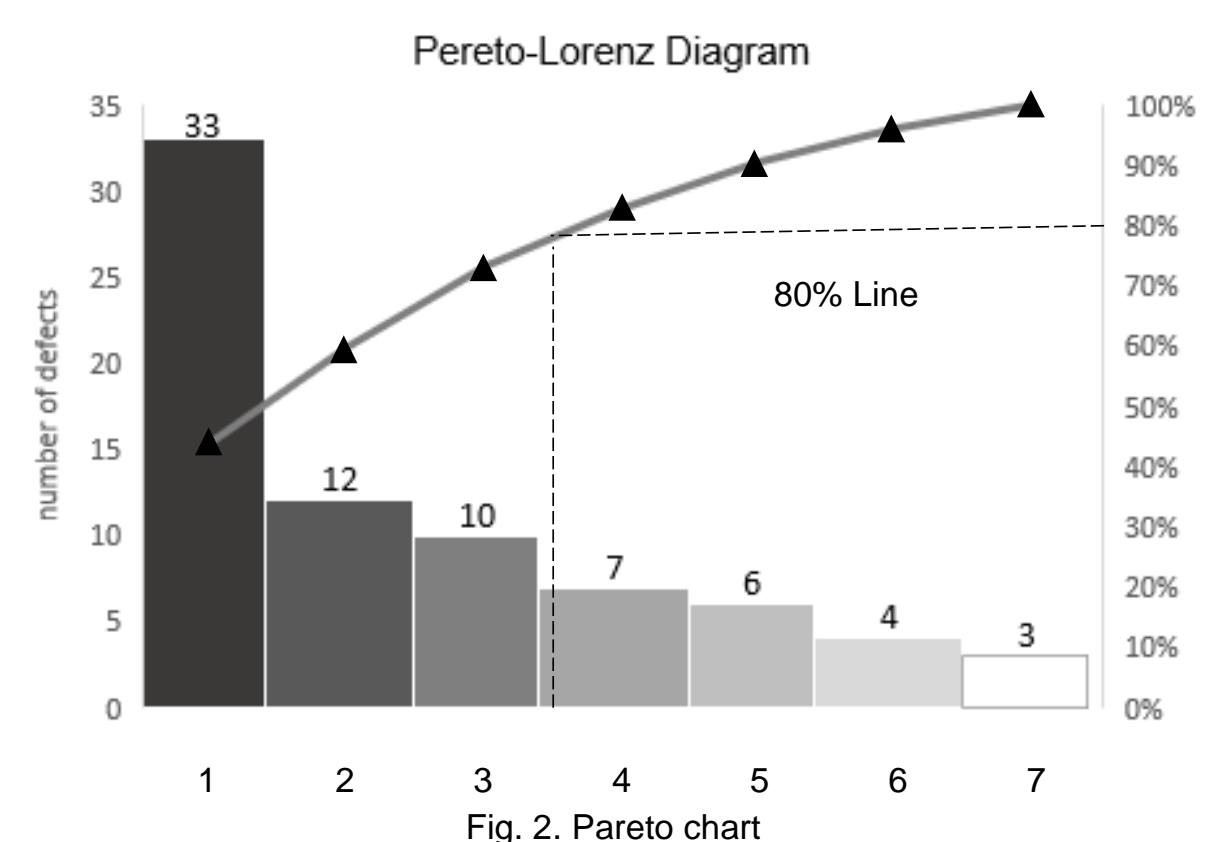

Analysis of the obtained graph allows to detect irregularities and implementing corrective actions. The values of the bars indicate the results of the Pareto analysis the percentage share of individual causes. And the combined points forming the Lorenz curve - indicate the cumulative value.

The analysis of the Pareto-Lorenz diagram shows that the main causes of these noncompliance are: wrong shape of bottles, incorrect length of bottles and bubbles on the surface of the bottles. Applying corrective actions to these incompatibilities will bring the greatest results. The figure shows that $73 \%$ of defects arise in the production process because of wrong shape of bottles, incorrect length of bottles and bubbles on the surface of the bottles. The elimination of these defects is crucial to improve the quality (Hibner, 2017). It can also be stated that non-compliances wrong shape of bottles, incorrect length of bottles and bubbles on the surface of the bottles they account for $80 \%$ of all non-compliances arising during the bottle production process. Bottle cracks, formation of several layers of the bottle, the formation of threads or streaks on the bottle and too slow change in the color of the bottle they account for only $20 \%$ of all non-conformities.

In order to properly take corrective and improvement actions, the cause of the noncompliance should be correctly identified.

To this end, the Ishikawa Diagram was used. The creator of this tool is Kaoru Ishikawa. The most important feature of this tool is a graphical representation of interrelationships causes of a specific effect. This diagram has a shape resembling a fish bone, wherein "Fish Head" indicates a problem to solve. "Backbone" refers to a group that may cause the occurrence of the problem. "Fish bones" mean reasons included in a given group. Ishikawa's diagram is designed to identify the causes of the most common quality problem during manufacturing bottles (Luca, 2016). The most known Ishikawa models are $4 \mathrm{M}, 5 \mathrm{M}, 6 \mathrm{M}$, the initials being in order: materials, methods, man, machines, mother 
nature, management. According to this concept, the analysis focuses on the main five groups of causes 5M: materials, methods, man, machines, management. Very often the Ishikawa diagram is considered in the $5 M+E$ system, where an additional sixth element is the environment. The results of the use of the Ishikawa diagram for identification causes of non-compliance - the incorrect shape of PET bottles based on categories $5 \mathrm{M}+\mathrm{E}$ is shown in Fig. 3 .

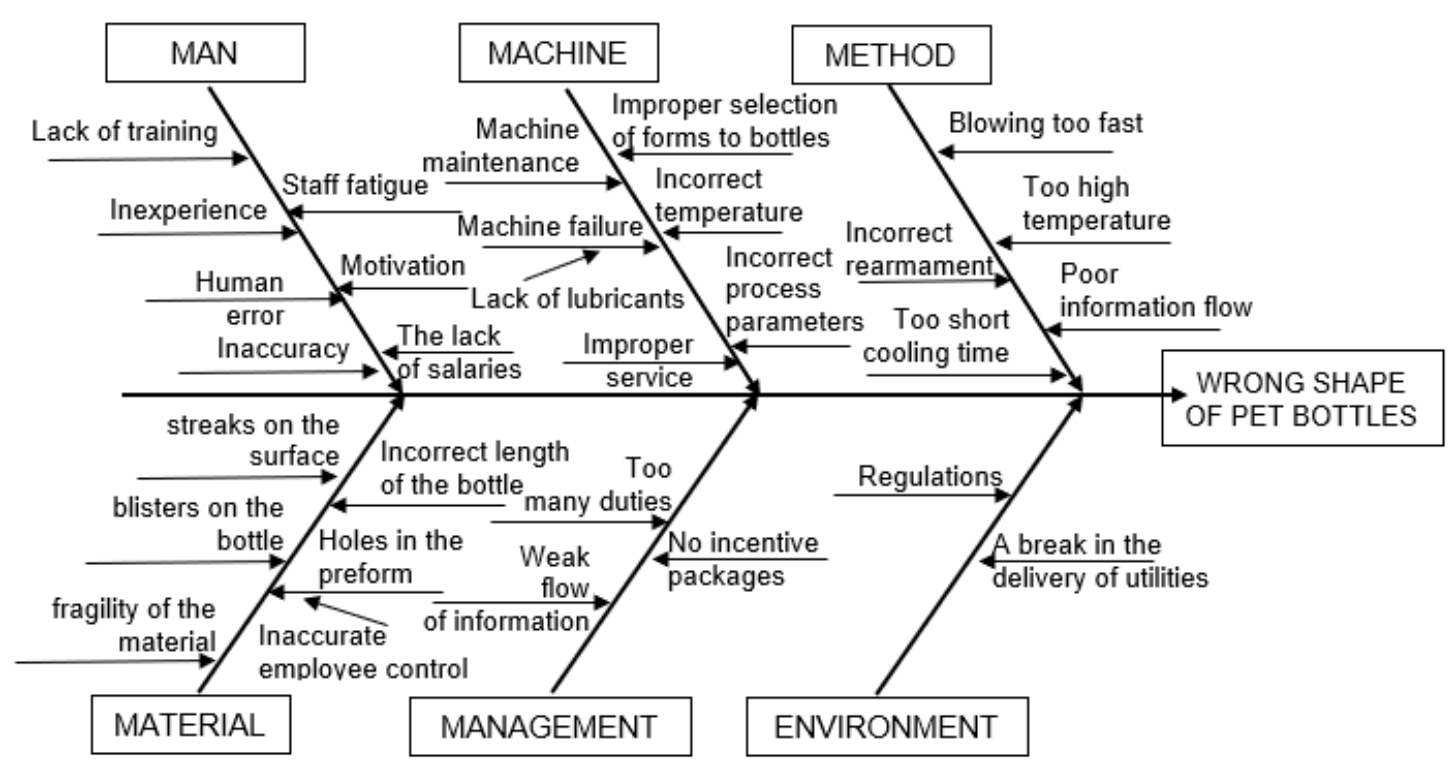

Fig.3. Ishikawa diagram: Factors contributing to defect wrong shape of PET bottle

Analysis of the problem using the Ishikawa diagram allows to identify the following main causes of the problem. The choice of $5 \mathrm{M}+\mathrm{E}$ category allowed to identify the factors responsible for a given problem. For each of the highlighted categories, improvement activities were defined. When considering the first category of man, it serves a very important role in the whole organization. Responsible for the entire production process, condition of machines and equipment. Employees with low qualifications make more mistakes, which causes more defective products. In order to improve this indicator, more training should be planned. Training can be carried out in an organization or at a certified training center. In order to increase the frequency of training to be completed, it is advisable to introduce employee training cards. Another equally important indicator is the lack of an adequate level of employee motivation. In order to increase the motivation of employees, it is necessary to implement an internal bonus system or to distinguish one employee from various departments every month. In addition, better working conditions should be created for employees, in a better way to appreciate their activity in the area of improvement activities. This procedure allows you to effectively reduce the level of non-compliance (Cirtina, 2012).

In the second category, the wrong shape of the PET bottle maybe caused by incorrect setting of the machine parameters. Machine operation should be carried out by persons with appropriate competences and experience. In addition, each person should check the machine parameters at specific intervals. Improper operation of the machine can lead to damage to it, causing temporary and quantitative losses. In order to reduce losses, it is recommended to assess the state of knowledge of employees responsible for the blow molding machines. The assessment of employees' weaknesses allows to 
properly determine the elements that require further improvement and professional improvement. Support for weaker competences of employees should be reduced in the shortest possible time (Wilczarska, 2012).

Behind the incorrect shape of the bottle they are primarily the responsibility of the process parameters. It should be remembered that the parameters vary depending on the capacity of the bottles. Bottles of lower capacity require different heating temperatures and other cooling times as opposed to large capacity bottles. In order to ensure proper working conditions, the inspection station should be prepared accordingly, paying attention to the necessary documentation about the production process being carried out. Always available and supplemented documentation allows you to control the production process. The availability of documentation also allows you to reduce the indicator of incorrect internal communication.

Incorrect shape of the finished bottle is caused by errors created in the production process. Among the most common defects should be indicated: Incorrect shape of PET bottles, incorrect length of bottles, bubbles on the surface of the bottles, bottle cracks, formation of several layers of the bottle, the formation of threads or streaks on the bottle, too slow change in the color of the bottle (Wróbel, 2010). In order to eliminate the above non-conformities, randomly selected preforms should be inspected prior to production. If the above actions do not bring the expected results, the process of their creation should be investigated. The selection of an appropriate supplier of semi-finished products is very important in the whole process. Each order should have the appropriate product specification.

In the case of management, errors related to the incorrect shape of the bottle can be caused by many factors. These inconsistencies may result from inadequate internal communication. Too many duties per employee. No exact operation by the employee. Insufficient supervision of superiors, which often involves a sense of less control. Proper management of people is also appropriate to support them in difficult situations for help in solving problems (Mielczarek et al., 2015).

The wrong shape of the bottle is caused by interruptions in access to electricity or water. It is recommended that each production sector organization have an additional power source. Doing so will protect your organization against halting the process of blowing bottles (Jacak et al., 2010).

As a result of Ishikawa's analysis and the Pareto-Lorenz diagram, a number of actions improving the process were proposed. The problem of inadequate choice of process parameters was solved by introducing checklists for operators and a technologist to facilitate the systematic control of process parameters. As a preventive measure, it was proposed to install sensors together with an IT system for process monitoring. For the reason of the inadequate frequency of inspections of machines and devices involved in the production process, a work maintenance scheduling system was implemented, taking into account the necessary inspections and repairs of machines and coordination with the production planning department. As a preventive measure, work cards for maintenance workers were introduced as well as the obligation to submit monthly reports on the work carried out in the schedule (Giridharreddy et al., 2013).

\section{CONCLUSION}

The object of the research was to recognize the process of PET bottle formation. The subject of the research was a food sector enterprise located in central Poland. In order to analyze the quality problems of the tested products, two quality management tools 
were used, ie the Pareto-Lorenz diagram and the Ishikawa diagram. As a result of these tools, the most important quality problems were identified.

On the basis of the analysis of the production process of PET bottles, defects were discovered, which caused delays in production and economic losses. The most important errors detected in the process are: incorrect shape of PET bottles, incorrect length of bottles, bubbles on the surface of the bottles, bottle cracks, formation of several layers of the bottle, the formation of threads or streaks on the bottle and too slow change in the color of the bottle.

The following corrective actions were proposed:

For reasons of inadequate choice of process parameters, as a corrective action, checklists for operators and a technologist were introduced to facilitate the systematic control of process parameters. As a preventive measure, it was proposed to install sensors together with an IT system for process monitoring.

For reasons of inadequate frequency of inspections of machines and devices involved in the production process, a work maintenance scheduling system was implemented, including the necessary inspections and repairs of machines and coordination with the production planning department. As a preventive measure, work cards for maintenance workers were introduced as well as the obligation to submit monthly reports on the work carried out in the schedule.

Corrective actions to improve the quality of PET bottles should primarily focus on the identification of "weak" and "strong" employee sides. To this end, it was proposed to conduct an in-depth analysis of how well the employees perform the tasks entrusted to them in order to identify those sites that need improvement. To assess the degree of employees' skills, the use of employee competency cards was proposed.

\section{REFERENCES}

Biały W., Skotnicka-Zasadzeń B., 2011. An analysis of possibilities to use a Pareto chart for evaluating mining machines' failure frequency, Maintenance and Reliability $\mathrm{nr} 3$.

Cirtina L. M., 2012. Improving the quality of processes by drawing cause-effect diagram using software instruments, $12 \mathrm{~h}$ International Multidisciplinary Scientific Geoconference (SGEM), (Albena) Vol. IV, pp. 1017-1021.

Giridharreddy K., Rajagopal K., Tech M., and D Ph, 2013. Blow Mould Tool Design and Manufacturing Process for 1litre Pet Bottle, Journal of Mechanical and Civil Engineering, 8, 12-21.

Hibner M. 2017. Wykorzystanie diagramu Pareto-Lorenza do analizy postojów/przestojów odstawy urobku, Zeszyty Naukowe Państwowej Wyższej Szkoły Zawodowej im. Witelona w Legnicy, nr 3 (2).

Ilie G., Ciocoiu C.N., 2010. Application of fishbone diagram to determine the risk of an event with multiple causes, MANAGEMENT RESEARCH AND PRACTICE Vol. 2 Issue 1, p: 1-20.

Jacak P., Jagusiak M., Ulewicz R., 2010. Identyfikacja przyczyn niezgodności preform PET, Aktualne problemy zarządzania jakością i personelem. Gąsiorowska A., Minta S. (red.). Stowarzyszenie Aktywnego Wspierania Gospodarki, Wrocław s. 68-74.

Kowalik K., 2018. Pareto-Lorenz Diagram in theory and practice of quality management. ARCHIVES OF ENGINEERING KNOWLEDGE VOL. 3 ISSUE 1(2018), 22-24. 
Kruszelnicka W., Bałdowska-Witos P., Flizikowski J., Tomporowski A., Ropińska P., Ignaczak P., 2018. The blowing process of a pet bottles, International Scientific Journal "Machines, Technologies. Materials.", 313-315, WEB ISSN 1314-507X.

Kuczenski B., Geyer R., 2011. Life Cycle Assessment of Polyethylene Terephthalate (PET), Beverage Bottles Consumed in the State of California, Drrr-2014-1487.

Luca L., 2016. A new model of Ishikawa diagram for quality assessment, IOP Conf. Series: Materials Science and Engineering 161, doi:10.1088/1757899X/161/1/012099.

Ładoński W., Szołtysek K., 2008. Metody kształtowania jakości w organizacji, Zarządzanie jakością, Część 3, Skrypty, Wydawnictwo Akademii Ekonomicznej im. Oskara Langego, Wrocław.

Mazur A., Gołaś H., 2010. Zasady, metody i techniki wykorzystywane w zarządzaniu jakością. Wydanie I, Projekt Wiedza Dla Gospodarki nr POKL 04.01.01-00-250/09, Wydawnictwo Politechniki Poznańskiej.

Mielczarek K., Knop K., 2015. Factors Deciding on the Enterprise Concept Development in the Production of Plastics, W: Quality Improvement Practice in Different Branches, Borkowski S., Rosak-Szyrocka J. (red.). Oficyna Wydawnicza Stowarzyszenia Menedżerów Jakości i Produkcji, Częstochowa, 142-153.

Ullah M., Khan A. M., Nawaz R., Akhtar R., 2016. Process Improvement for PET Bottles Manufacturing Company Using Six Sigma Approach, Pakistan, Technical Journal, University of Engineering and Technology (UET) Taxila, Vol. 21 No. II.

Ullah M., Khan A.M., Nawaz R., Akhtar R., 2016. Process Improvement for PET Bottles Manufacturing Company Using Six Sigma Approach, 1-9.

Wilczarska J., 2012. Efektywność i bezpieczeństwo użytkowania maszyn, Inż. i Ap. Chem. 2, 41-43.

Wróbel P., 2010. Analiza funkcjonowania maszyn na przykładzie wybranego przedsiębiorstwa, Praca zrealizowana pod opieką K. Antosz, Rzeszów, Politechnika Rzeszowska.

http://www.cityprocessmanagement.com/Downloads/CPM_5Ys.pdf

http://www.nursingtimes.net/Journals/2013/04/12/k/x/z/Using-fishbone-analysis--toinvestigateproblems-160413.pdf [15] Dale, B G 1994 Managing 